\title{
Effect of agricultural pesticide on precocious puberty in urban children: an exploratory study
}

\author{
Junghwan Suh, MD, Han Saem Choi, MD, Ahreum Kwon, MD, Hyun Wook Chae, MD, Ho-Seong Kim, MD, PhD \\ Department of Pediatrics, Severance Children's Hospital, Endocrine Research Institute, Yonsei University College of Medicine, Seoul, Korea
}

Background: The incidence of precocious puberty has increased throughout the 20th century. The association between precocious puberty and endocrine disrupting chemicals including agricultural pesticides has been a subject of global study, but human data are lacking.

Purpose: We investigated the relationship between agricultural pesticides and the development of precocious puberty.

Methods: We enrolled 60 female subjects at Severance Children's Hospital from December 2015 to January 2017. Of them, 30 were diagnosed with precocious puberty, while the other 30 prepubertal girls were enrolled as normal controls. We investigated their clinical characteristics and analyzed the urinary levels of 320 different agricultural pesticides.

Results: Agricultural pesticide was detected in one of 30 patients with precocious puberty (3.3\%) versus 2 of 30 girls in the normal control group ( $3.3 \%$ vs. $6.7 \%, P=0.554)$. Dinotefuran, a neonicotinoid-class insecticide, was detected in the samples of all 3 positive subjects.

Conclusion: Our results showed no relationship between agricultural pesticides and the development of precocious puberty. Larger sample sizes and robustly controlled variables are necessary to further investigate this topic.

Key words: Endocrine disrupting chemicals, Agricultural pesticide, Precocious puberty

\section{Key message}

Question: Does agricultural pesticide effect precocious puberty in girls?

Finding: Dinotefuran, an insecticide of neonicotinoid class, was detected in one of 30 patients with precocious puberty, and in 2 girls of the normal control group, which was not statistically significant.

Meaning: There was no close relationship between agricultural pesticides and development of precocious puberty.

\section{Introduction}

Advanced pubertal timing and increasing incidence of precocious puberty have been observed worldwide throughout the last century. Previously, these trends were largely explained by im. proved public health and nutrition, but endocrine disrupting chemicals (EDCs) are recently drawing public scrutiny. EDCs are exogenous substances or mixtures that alter functions of the endocrine system, ${ }^{1}$ including bisphenol A (BPA), phthalates, heavy metals, agricultural pesticides, and pollutants such as dioxin and polychlorinated biphenyls, among others. Recent studies have reported an association between EDCs and pubertal timing in humans and in animal models, but a conclusive relationship remains controversial. For example, BPA was once reported to have estrogenic effects causing precocious puberty in girls, ${ }^{2}$ but other studies showed no direct relationship between urinary BPA level and early puberty onset. ${ }^{3,4)}$ Also, phthalates have been highlighted as influencing precocious puberty, and have been widely investigated in humans and in animal models, but outcomes from these studies are inconclusive. ${ }^{5-7)}$

Pesticides, which have been increasingly used in modern agriculture industry, have been investigated for agonistic or antagonistic effects on the endocrine system. ${ }^{8)}$ Dichlorodiphenyltrichloroethane and its metabolites have estrogenic effects on the endocrine system, causing precocious puberty. ${ }^{9}$ ) Methoxychlor and endosulfan were also reported to have estrogenic effects by directly binding to estrogen receptors, increasing estrogen sensitivity, or stimulating endogenous estrogen production through the gonadotropin-releasing hormone $(\mathrm{GnRH})$ system. ${ }^{10,11)}$ Meanwhile, the fungicide prochloraz showed antiestrogenic effects in animal models, ${ }^{12)}$ while exposure to organochlorine pesticides was associated with delayed pubertal development. ${ }^{13)}$ In particular, the matter of contaminated egg with insecticides attracted intense public attention in Belgium and Korea in 2017. ${ }^{14)}$

However, there is an insufficient human subject data about the effects of pesticides, especially in Korean subjects. Therefore, we investigated the relationship between agricultural pesticides and development of precocious puberty.

\footnotetext{
Corresponding author: Ho-Seong Kim, MD, PhD. Department of Pediatrics, Severance Children's Hospital, Endocrine Research Institute, Yonsei University College of Medicine, 50-1 Yonsei-ro, Seodaemun-gu, Seoul 03722, Korea 


\section{Methods}

\section{Study participants}

We enrolled 60 female subjects at Severance Children's Hospital from December 2015 to January 2017. Thirty patients were diagnosed with precocious puberty based on peak luteinizing hormone (LH) level over $5 \mathrm{mIU} / \mathrm{mL}$ on a GnRH stimulation test, and 30 prepubertal girls were classified into the normal control group. We analyzed patient anthropometric data, laboratory results, and bone age, and we sent blood and urine samples to the Korea Agriculture Food Analysis Institute for analysis of agricultural pesticides. A total of 320 kinds of agricultural pesticides, including dichlorodiphenyldichlorethylene (DDE) (geometric mean $1.45 \mathrm{ng} / \mathrm{g}$ ) and hexachlorobenzene (geometric mean 0.092 $\mathrm{ng} / \mathrm{g}$ ), were analyzed by liquid chromatography mass spectrometry (LC-MS/MS) and gas chromatography mass spectrometry (GC-MS/MS) (Supplementary material 1). The present study protocol was reviewed and approved by the Institutional Review Board of Yonsei University Health System in Seoul, Korea (approval number: 4-2019-0040). Informed consent was submitted by all subjects when they were enrolled.

\section{Biochemical and clinical assessment}

Baseline characteristics of age, height, weight, body mass index (BMI), LH, follicle-stimulating hormone (FSH), estradiol, and bone age were examined during each patient' first clinic visit. $\mathrm{LH}$ and FSH serum levels were estimated using sequential 2-step immunoenzymatic assay (Access hLH, FSH Reagent Pack; Beckman Coulter Inc., La Brea, CA, USA) with an intra-assay coefficient of variation (CV) of 3.5\%-5.4\%, an interassay CV of $4.3 \%-6.4 \%$, and a lower limit of detection of $0.2 \mathrm{IU} / \mathrm{L}$ for both gonadotropins. Serum estradiol level was measured via radioimmunoassay (Coat-A-Count Estradiol; Siemens, Erlangen, Germany) with an intra-assay CV of 4.0\%-7.0\%, an interassay CV of 4.2\%-8.1\%, and a lower limit of detection of $8 \mathrm{pg} / \mathrm{mL}$. Bone age was determined using the Greulich-Pyle method with radiography on the left hand and wrist. Height standard deviation score (SDS), weight SDS, and BMI SDS were calculated from the 2017 Korean children and adolescents' growth standard. ${ }^{15)}$

\section{Urine sample preparations}

Urine samples were collected into 50-mL Falcon tube (BD Biosciences, San Jose, CA, USA) in the early morning and stored at $-20^{\circ} \mathrm{C}$ until pesticide residue analyses. Urine chemical analyses were carried out by the Korea Agriculture Food Analysis Institute. Sample pretreatment was carried out with QuEChERS (quick, easy, cheap, effective, rugged, and safe) and dispersive solid phase extraction (dSPE) kits (EN15662 method). ${ }^{16,17)}$ Two millimeters each of prepared sample (urine) and acetonitrile $(\mathrm{MeCN})$ was dispensed into a centrifuge tube along with internal standard solution (0.1-mg/L triphenyl phosphate). The tubes were then vortexed for 1 minute on a shaker at maximum speed. Mixed samples were treated with 4-g $\mathrm{MgSO}_{4}, 1-\mathrm{g} \mathrm{NaCl}, 1$-g trisodiumcitrate dihydrate, and 0.5 -g disodium hydrogencitrate sesquihydrate and were vortexed for 1 minute at maximum speed. After the reaction was complete, the tubes were centrifuged at 4,500 rpm for 5 minutes. Next, $1 \mathrm{~mL}$ of supernatant was transferred to a dispersive SPE tube containing 25-mg primary-secondary amine, and $150-\mathrm{mg} \mathrm{MgSO}_{4}$ and mixed for 1 minute. Finally, the tube was centrifuged at 12,000 rpm for 5 minutes and the supernatant was filtered through a $0.2-\mu \mathrm{m}$ syringe filter.

\section{Preparation of standard pesticide solutions and reagents}

Standard pesticide solutions were purchased from Ultra Scientific (North Kingston, RI, USA). Triphenylphosphate, which was used as an internal standard was purchased from Sigma-Aldrich (St. Louis, MO, USA). Pesticide grade acetonitrile $(\mathrm{MeCN})$ was purchased from Duksan (Seoul, Korea). The GCMS-TQ8050 (GC-MS/MS) and LCMS-TQ8050 (LC-MS/ MS) analytical instruments were from Shimadzu (Kyoto, Japan).

\section{LC-MS/MS condition}

LC-MS/MS analysis was performed to detect pesticide components in the urine samples, ${ }^{18)}$ using the following conditions; a Capcell Core C18 column ( $2.1 \mathrm{~mm} \times 150 \mathrm{~mm}, 2.7 \mu \mathrm{m}), 3-\mu \mathrm{L}$ injection volume, and $40^{\circ} \mathrm{C}$ column temperature. Ionization was performed by electrospray ionization (polarity, positive). Two mobile phases were used; mobile A contained $0.1 \%$ formic acid and $5 \mathrm{mM}$ ammonium formate in water; mobile $\mathrm{B}$ contained $0.1 \%$ formic acid and $5 \mathrm{mM}$ ammonium formate in methanol. The flow rate was $0.3 \mathrm{~mL}$ per minute. Flow rates and times are shown in Supplementary material 2.

\section{GC-MS/MS condition}

The GCMS-TQ8050 instrument from Shimadzu (Kyoto, Japan) was used with the Rxi-5MS capillary column (length, 20 $\mathrm{mm}$; inner diameter, $0.18 \mathrm{~mm}$; film thickness, $0.18 \mu \mathrm{m}$; Restek, Bellefonte, PA, USA) for gas chromatography mass spectrometry. The inlet temperature was $260^{\circ} \mathrm{C}$, and the column flow rate was $1 \mathrm{~mL}$ per minute. The injection volume was $1 \mu \mathrm{L}$, and the splitless mode was used. During GCMS-TQ8050 analysis, the interface temperature was maintained at $250^{\circ} \mathrm{C}$.

\section{Statistical analyses}

Statistical analyses were performed using IBM SPSS ver. 23.0 (IBM Co., Armonk, NY, USA). Two-sample $t$ test was used to compare baseline characteristics between the 2 groups, and the chi-square test was used to evaluate the association between precocious puberty and positive agricultural pesticides results. A $P$ value $<0.05$ was considered statistically significant.

\section{Results}

Our study population of 60 girls consisted of 30 precocious puberty patients and 30 normal controls. Baseline characteristics were compared between the 2 groups based on data from their first clinic visit (Table 1). The precocious puberty group was 
older than the normal control group (8.5 \pm 0.7 years vs. $7.0 \pm 1.4$ years, $P<0.001$ ), and SDS for height, weight, and BMI were significantly higher in the puberty group. Serum LH and FSH were elevated in the precocious puberty group, but estradiol level was not significantly different. Bone age was advanced in the precocious puberty group $(10.58 \pm 0.69$ years vs. $6.78 \pm 1.87$ years, $P<0.001)$, and differences between bone age and chronological age were larger in the puberty group $(2.0 \pm 0.5$ years vs. $-0.3 \pm 0.8$ years, $P<0.001)$.

Agricultural pesticide was detected in one out of 30 patients with precocious puberty (3.3\%), while 2 girls in the normal control group had positive results (6.7\%), which was not statistically significant $(P=0.554)$ (Table 2). Dinotefuran, a neonicotinoid pesticide, was detected in all 3 subjects with positive agricultural pesticide results (Table 3 ).

\section{Discussion}

Severe environmental pollution and increasing public interest in health and well-being have increased people's anxiety about potentially harmful chemicals, but human data is insufficient. In this study, we analyzed 320 kinds of agricultural pesticides in

Table 1. Baseline characteristics

\begin{tabular}{lccr}
\hline Characteristic & Precocious puberty group & Control group & $P$ value \\
\hline Age $(\mathrm{yr})$ & $8.53 \pm 0.68$ & $7.03 \pm 1.36$ & $<0.001$ \\
Height $(\mathrm{cm})$ & $131.93 \pm 6.92$ & $113.34 \pm 8.28$ & $<0.001$ \\
Height SDS & $0.36 \pm 0.89$ & $-1.58 \pm 0.61$ & $<0.001$ \\
Weight $(\mathrm{kg})$ & $31.11 \pm 6.92$ & $19.72 \pm 4.05$ & $<0.001$ \\
Weight SDS & $0.22 \pm 1.12$ & $-1.42 \pm 0.87$ & $<0.001$ \\
BMI $\left(\mathrm{kg} / \mathrm{m}^{2}\right)$ & $17.71 \pm 2.84$ & $15.23 \pm 1.63$ & $<0.001$ \\
BMI SDS & $0.22 \pm 1.12$ & $-0.73 \pm 0.93$ & 0.001 \\
LH & $0.62 \pm 0.64$ & $0.3 \pm 0.24$ & 0.015 \\
FSH & $3.34 \pm 1.68$ & $2.1 \pm 1.36$ & 0.003 \\
Estradiol & $8.02 \pm 0.12$ & $8 \pm 0$ & 0.326 \\
Bone age (yr) & $10.58 \pm 0.69$ & $6.78 \pm 1.87$ & $<0.001$ \\
BA-CA (yr) & $2.04 \pm 0.49$ & $-0.25 \pm 0.77$ & $<0.001$ \\
\hline V & & &
\end{tabular}

Values are presented as mean \pm standard deviation.

SDS, standard deviation score; BMI, body mass index; LH, luteinizing hormone; $\mathrm{FSH}$, follicle-stimulating hormone; $\mathrm{BA}$, bone age; $\mathrm{CA}$, chronological age.

Table 2. Pesticide detection results

\begin{tabular}{cccc}
\hline & Precocious puberty group & Control group & $P$ value \\
\hline Pesticide detected & $1 / 30(3.3)$ & $2 / 30(6.7)$ & 0.554
\end{tabular}

Values are presented as number (\%).
60 girls. Dinotefuran was detected in 3 girls, one in precocious puberty group and 2 in control group, but the results were not statistically significant.

Several previous studies have evaluated links between agri cultural pesticides and pubertal development, but most were animal experiments. ${ }^{19)}$ Some animal models have demonstrated a relationship between agricultural pesticides and precocious puberty, but the outcomes from human research have been less conclusive. Some human studies about pesticide exposure and precocious puberty have yielded similar results to ours. Ozen et al., ${ }^{20)}$ reported that pesticide presence and levels in serum and adipose tissue were not related to precocious puberty. Another study from China compared precocious puberty patients with a normal control group and found no differences in DDE level between the groups. ${ }^{21)}$ Also, a previous analysis of a population in New York City, with a similar environmental context to our study, found no significant relationship between EDC level and pubertal development; rather, they found some associations with delayed breast development. ${ }^{22)}$ Recent studies investigating the association between pesticide and puberty are described in Table $4 .^{13,20-23)}$

Dinotefuran is an insecticide of the neonicotinoid class and is widely used for its long residual activity and broad spectrum against insects. The mean aerobic biodegradation half-life of dinotefuran measured in soils was 81.5 days, and it can be exposure to humans through inhalation of dust and dermal contact at workplaces. However, some European Union countries and several states in the United States have restricted the use of certain neonicotinoids because of their harmful effect on bees. ${ }^{24)}$ Also, animal models have shown a variety of potential toxicities of neonicotinoids, including reproductive toxicity, hepatotoxicity, and neurotoxicity. ${ }^{25)}$ Kapoor et al. ${ }^{26)}$ reported decreased ovarian weight with patho-morphological changes in follicles in female rats, and Bal et al. ${ }^{27)}$ reported deterioration in sperm parameters and decreased testosterone in adult male rats. However, human subject data are insufficient to determine whether neonicotinoids have deleterious effects on humans, despite the general population already being commonly exposed in many countries. ${ }^{28,29)}$ Although no studies have reported a significant association between precocious puberty and neonicotinoid exposure, further research into the effects of dinotefuran, in particular, would be desirable because it was the only agricultural pesticide detected in our study.

A major limitation of our study is that the precocious puberty group and control group were not homogeneous. Anthropometric data including age, height, weight, and bone age of control group were not matched with precocious puberty group, which

Table 3. Pesticide-positive cases according to detection analysis

\begin{tabular}{lcccccrc}
\hline No. & Age $(\mathrm{yr})$ & Bone age $(\mathrm{yr})$ & Pubertal status & Height $(\mathrm{cm})(\mathrm{SDS})$ & Weight $(\mathrm{kg})(\mathrm{SDS})$ & \multicolumn{1}{c}{ BMI $\left(\mathrm{kg} / \mathrm{m}^{2}\right)(\mathrm{SDS})$} & Pesticide detected \\
\hline 1 & 7.2 & 9.25 & Pubertal & $120.1(-0.45)$ & $19.8(-1.4)$ & $13.73(-1.65)$ & Dinotefuran $(0.0524 \mathrm{mg} / \mathrm{kg})$ \\
2 & 7.7 & 7 & Prepubertal & $117.7(-1.45)$ & $20.2(-1.58)$ & $14.58(-1.09)$ & Dinotefuran $(0.0426 \mathrm{mg} / \mathrm{kg})$ \\
3 & 8.8 & 9.25 & Prepubertal & $123(-1.56)$ & $23.9(-1.24)$ & $15.8(-0.61)$ & Dinotefuran $(0.0316 \mathrm{mg} / \mathrm{kg})$ \\
\hline
\end{tabular}

SDS, standard deviation score; BMI, body mass index. 
Table 4. Summary of recent studies on association between pesticide and puberty

\begin{tabular}{|c|c|c|c|c|}
\hline Study & Country & Subjects & Pesticides & Results \\
\hline $\begin{array}{l}\text { Ozen et al. }{ }^{20)} \\
(2012)\end{array}$ & Turkey & $\begin{array}{l}45 \text { Girls with premature } \\
\text { breast development, } \\
49 \text { controls }\end{array}$ & $\begin{array}{l}\text { Endosulphan 1, endosulphan 2, endosulphan } \\
\text { sulphate, methoxychlor, vinclozolin, 4,4- } \\
\text { DDE, 4-DDT, 2,4-DDT }\end{array}$ & $\begin{array}{l}\text { The presence and levels of pesticides in } \\
\text { serum and adipose tissues were not relat- } \\
\text { ed to precocious puberty }\end{array}$ \\
\hline $\begin{array}{l}\text { Deng et al. }{ }^{21)} \\
(2012)\end{array}$ & China & $\begin{array}{l}78 \text { Precocious puberty } \\
\text { patients, } 100 \text { controls }\end{array}$ & ZEA, p,p'-DDE & $\begin{array}{l}\text { No difference in the concentration of } p, p^{\prime} \\
\text {-DDE between the } 2 \text { groups }\end{array}$ \\
\hline $\begin{array}{l}\text { Wolff et al. }{ }^{22)} \\
(2008)\end{array}$ & USA & 186 Girls & Phytoestrogen, DDE, PCB, Pb, BPA & $\begin{array}{l}\mathrm{DDE}, \mathrm{Pb} \text {, and dietary intakes of phytoe- } \\
\text { strogens were not significantly associated } \\
\text { with breast stage }\end{array}$ \\
\hline $\begin{array}{l}\text { Bapayeva et al. }{ }^{23)} \\
(2016)\end{array}$ & Kazakhstan & 524 Girls & Lindane, dieldrin, DDT, endrin & $\begin{array}{l}\text { Increased concentrations of pesticides in } \\
\text { the blood of females is associated with de- } \\
\text { layed sexual development }\end{array}$ \\
\hline $\begin{array}{l}\text { Lam et al. }{ }^{13)} \\
(2014)\end{array}$ & Russia & 350 Boys & $\mathrm{HCB}, \beta-\mathrm{HCH}, \mathrm{p}, \mathrm{p}^{\prime}-\mathrm{DDE}$ & $\begin{array}{l}\text { Higher prepubertal serum HCB concentra- } \\
\text { tions were associated with later age of } \\
\text { gonadarche and pubarche }\end{array}$ \\
\hline
\end{tabular}

$\overline{\mathrm{DDE}}$, dichlorodiphenyldichlorethylene; DDT, dichlorodiphenyltrichloroethane; ZEA, zearalenone; $\mathrm{p}, \mathrm{p}^{\prime}$-DDE, 1,1-dichloro-2,2,bisethylene; PCB, polychlorinated biphenyls; Pb, lead; BPA, bisphenol A; $\mathrm{HCB}$, hexachlorobenzene; $\beta-\mathrm{HCH}, \beta$-hexachlorocyclohexane.

could have resulted in biased conclusions. Also, our sample size of 60 patients was insufficient to draw robust results. Lastly, this study was performed at Severance Children's Hospital, which is located in Seoul, the capital city of Korea. Residents in urban areas are less likely to be exposed to agricultural pesticides.

In conclusion, our results showed no close relationship between agricultural pesticides and development of precocious puberty. Larger sample sizes and well-controlled variables are necessary for future investigations.

\section{Conflicts of interest}

No potential conflict of interest relevant to this article was reported.

\section{Acknowledgments}

This research was supported by the Basic Science Research Program through the National Research Foundation of Korea (NRF) funded by the Ministry of Science, Information \& Communication Technology, and Future Planning (2014R1A2A2A0 1002421).

\section{Supplementary materials}

Supplementary material can be found via https://doi.org/ 10.3345/cep.2019.00416.

Supplementary material 1 . List of analyzed pesticides. Supplementary material 2 . Flow rates and timing for liquid chromatography mass spectrometry conditions.

\section{References}

1. Bergman Å, Heindel J, Jobling S, Kidd K, Zoeller RTJTL. State-of-thescience of endocrine disrupting chemicals, 2012 2012:S3.

2. Durmaz E, Asci A, Erkekoglu P, Akcurin S, Gumusel BK, Bircan I. Urinary bisphenol a levels in girls with idiopathic central precocious puberty. J Clin Res Pediatr Endocrinol 2014;6:16-21.

3. Wolff MS, Teitelbaum SL, Pinney SM, Windham G, Liao L, Biro F, et al. Investigation of relationships between urinary biomarkers of phytoestrogens, phthalates, and phenols and pubertal stages in girls. Environ
Health Perspect 2010;118:1039-46.

4. Lee SH, Kang SM, Choi MH, Lee J, Park MJ, Kim SH, et al. Changes in steroid metabolism among girls with precocious puberty may not be associated with urinary levels of bisphenol A. Reprod Toxicol 2014;44:16.

5. Chen CY, Chou YY, Wu YM, Lin CC, Lin SJ, Lee CC. Phthalates may promote female puberty by increasing kisspeptin activity. Hum Reprod 2013;28:2765-73.

6. Wolff MS, Teitelbaum SL, McGovern K, Windham GC, Pinney SM, Galvez M, et al. Phthalate exposure and pubertal development in a longitudinal study of US girls. Hum Reprod 2014;29:1558-66.

7. Mouritsen A, Frederiksen H, Sorensen K, Aksglaede L, Hagen C, Skakkebaek NE, et al. Urinary phthalates from 168 girls and boys measured twice a year during a 5 -year period: associations with adrenal androgen levels and puberty. J Clin Endocrinol Metab 2013;98:3755-64.

8. Ozen S, Goksen D, Darcan S. Agricultural pesticides and precocious puberty. Vitam Horm 2014;94:27-40.

9. Nebesio TD, Pescovitz $\mathrm{OH}$. The role of endocrine disruptors in pubertal development. In: Pescovitz OH, Walvoord EC, editors. When puberty is precocious: scientific and clinical aspects. Totowa (NJ): Humana Press Inc., 2007:425-42.

10. Buck Louis GM, Gray LE Jr., Marcus M, Ojeda SR, Pescovitz OH, Witchel SF, et al. Environmental factors and puberty timing: expert panel research needs. Pediatrics 2008;121 Suppl 3:S192-207.

11. Jorgensen M, Vendelbo B, Skakkebaek NE, Leffers H. Assaying estrogenicity by quantitating the expression levels of endogenous estrogenregulated genes. Environ Health Perspect 2000;108:403-12.

12. Vinggaard AM, Nellemann C, Dalgaard M, Jørgensen EB, Andersen HR. Antiandrogenic effects in vitro and in vivo of the fungicide prochloraz. Toxicol Sci 2002;69:344-53.

13. Lam T, Williams PL, Lee MM, Korrick SA, Birnbaum LS, Burns JS, et al. Prepubertal organochlorine pesticide concentrations and age of pubertal onset among Russian boys. Environ Int 2014;73:135-42.

14. You M, Kang S, Park E, Lee M, Lee Y. Health authorities' and news media's responses to the 2017 pesticide detected eggs: evaluation and suggestions for better risk communication. Korean J Public Health 2017;54:21-33.

15. Kim JH, Yun S, Hwang SS, Shim JO, Chae HW, Lee YJ, et al. The 2017 Korean National Growth Charts for children and adolescents: development, improvement, and prospects. Korean J Pediatr 2018;61: 135-49.

16. Westland JL, Dorman FL. QuEChERS extraction of benzodiazepines in biological matrices. J Pharm Anal 2013;3:509-17.

17. Lucini L, Molinari GP. Performance and matrix effect observed in QuEChERS extraction and tandem mass spectrometry analyses of pesticide residues in different target crops. J Chromatogr Sci 2011;49:709-14.

18. Bang DY, Byeon SK, Moon MH. Rapid and simple extraction of lipids 
from blood plasma and urine for liquid chromatography-tandem mass spectrometry. J Chromatogr A 2014;1331:19-26.

19. Rasier G, Toppari J, Parent AS, Bourguignon JP. Female sexual maturation and reproduction after prepubertal exposure to estrogens and endocrine disrupting chemicals: a review of rodent and human data. Mol Cell Endocrinol 2006;254-255:187-201.

20. Ozen S, Darcan S, Bayindir P, Karasulu E, Simsek DG, Gurler T. Effects of pesticides used in agriculture on the development of precocious puberty. Environ Monit Assess 2012;184:4223-32.

21. Deng F, Tao FB, Liu DY, Xu YY, Hao JH, Sun Y, et al. Effects of growth environments and two environmental endocrine disruptors on children with idiopathic precocious puberty. Eur J Endocrinol 2012;166:803-9.

22. Wolff MS, Britton JA, Boguski L, Hochman S, Maloney N, Serra N, et al. Environmental exposures and puberty in inner-city girls. Environ Res 2008;107:393-400.

23. Bapayeva G, Issayeva R, Zhumadilova A, Nurkasimova R, Kulbayeva $S$, Tleuzhan R. Organochlorine pesticides and female puberty in South Kazakhstan. Reprod Toxicol 2016;65:67-75.

24. Van der Sluijs JP, Simon-Delso N, Goulson D, Maxim L, Bonmatin JM, Belzunces LP. Neonicotinoids, bee disorders and the sustainability of pollinator services. Curr Opin Environ Sustain 2013;5:293-305.

25. Han W, Tian Y, Shen X. Human exposure to neonicotinoid insecticides and the evaluation of their potential toxicity: an overview. Chemosphere 2018;192:59-65.

26. Kapoor U, Srivastava MK, Srivastava LP. Toxicological impact of technical imidacloprid on ovarian morphology, hormones and antioxidant enzymes in female rats. Food Chem Toxicol 2011;49:3086-9.

27. Bal R, Naziroglu M, Turk G, Yilmaz O, Kuloglu T, Etem E, et al. Insecticide imidacloprid induces morphological and DNA damage through oxidative toxicity on the reproductive organs of developing male rats. Cell Biochem Funct 2012;30:492-9.

28. Osaka A, Ueyama J, Kondo T, Nomura H, Sugiura Y, Saito I, et al. Exposure characterization of three major insecticide lines in urine of young children in Japan-neonicotinoids, organophosphates, and pyrethroids. Environ Res 2016;147:89-96.

29. Kavvalakis MP, Tzatzarakis MN, Theodoropoulou EP, Barbounis EG, Tsakalof AK, Tsatsakis AM. Development and application of LCAPCI-MS method for biomonitoring of animal and human exposure to imidacloprid. Chemosphere 2013;93:2612-20. 


\section{Supplementary material 1. List of analyzed pesticides}

Acrinathrin (2 isomer), Alachior Aldrin, Ametoctradin, Anilofos, Azaconazole, Benfuresate, BHC(alpha, beta, delta), Bifenox, Bifenthrin, Bromobutide, Bromopropylate, Butachlor, Butafenacil, Carbophenothion, Chlorantraniliprole, Chlordane (2 isomer), Chlorfenapyr, Chlorfenvinphos (2 isomer), Chlorfluazuron, Chlorobenzilate, Chlorpropham, Chlorpyrifos-methyl, Cyfluthrin (4 isomers), Cyhalothrin 1, Cypermethrin (4 isomers), Cyprodinil, Deltamethrin (tralomethrin), Diclofop-methyl, Dicloran, Dicofol, Dieldrin, Difenoconazole (2 isomer), Dimethoate, Dimethylvinphos, Diphenylamine, Disulfoton, Endosulfan(alpha), Endosulfan(beta), Endosulfan-sulfate, Endrin, EPN, Epoxiconazole, Ethalfluralin, Ethion, Etridiazole, Fenclorim, Fenitrothion, Fenothiocarb, Fenoxanil, Fenpropathrin, Fenthion, Fenvalerate (2 isomer), Fipronil, Flucythrinate (2 isomer), Flumioxazine, Fluopyram, Fonofos, Fthalide, Halfenprox, Heptachlor, Heptachlor-epoxide, Imibenconazole, Indanofan, Indoxacarb, Iprodione, Isazofos, Isofenphos, Mecarbam, Methidathion, Metolachlor, Metribuzin, Lindane(gamma-BHC), Oxyfluorfen, o,p-DDT, p,p-DDD, P,P-DDE, p,p-DDT, Parathion-ethyl, Parathion-methyl, Pendimethalin, Penthiopyrad, Permethrin (2 isomer), Phenothrin (2 isomer), Phorate, Phosalone, Picoxystrobin, Piperonyl butoxide, Pirimiphosethyl, Pretilachlor, Prochloraz, Procymidone, Promecarb, Prometryn, Propachlor, Propazine, Propiconazole (2 isomer), Propisochlor, Propyzamide, Prothiofos, Pyridalyl, Quintozene, Silafluofen, Simazine, Simeconazole, Simetryn, Spiromesifen, Tebupirimfos, Tefluthrin, Terbufos, Terbutryn, Tetradifon, Thifluzamide, Tolclofos-methyl (TPP), Triadimenol, Tri-allate, Trifluralin, Vinclozolin, Zoxamide, Abamectin BI, Acephate, Acetamiprid, Aldicarb,Amisulbrom, Azimsulfuron, Azinphos-methyl, Azoxystrobin, Bendiocarb, Bensulfuron-methyl, Benthiavalicarb-isopropyl, Benzobicyclon, Benzoximate,Bitertanol, Boscalid, Bromacil, Buprofezin, Cadusafos, Cafenstrole, Carbaryl, Carbendazim, Carbofuran, Carboxin, Carfentrazone-ethyl, Carpropamide, Chlorpyrifos, Chlorsulfuron, Chromafenozide, Clethodim, Clofentezine, Clomazone, Clothianidin, Cyazofamid, Cyclosulfamurom, Cyflufenamid, Cyhalofop-butyl, Cymoxanil, Cyproconazole(I, II), Dichlovos(DDVP), Demeton-S-Methyl, Diazinon, Diethofencarb, Diflubenzuron, Dimepiperate, Dimethametryn, Dimethenamid, Dimethomorph(E, Z), Diniconazole, Dinotefuran, Diphenamid, Dithiopyr, Diuron, Daimuron, Edifenphos, Esprocarb, Ethaboxam, Ethiofencarb, Etofenprox, Ethoprophos, Ethoxysulfuron, Etoxazole, Etrimfos, Famoxadone, Fenamiphos, Fenarimol, Fenazaquin, Fenbuconazole, Fenhexamid, Fenobucarb, Fenoxaprop-ethyl, Fenoxycarb, Fenpyroximate, Fentrazamide, Ferimzone(E, Z), Flonicamid, Fluacrypyrim, Flubendiamide, Flucetosulfuron, Fludioxonil, Flufenacet, Flufenoxuron, Fluopicolide, Fluxapyroxad, Fluquinconazole,Flusilazole, Flutolanil, Forchlorfenuron, Fosthiazate, Furathiocarb, Gibberellic acid, Halosulfuron-methyl, Haloxyfop, Hexaconazole, Hexaflumuron, Hexazinone, Hexythiazox, Imazalil, Imazosulfuron, Imicyafos, Imidacloprid, Inabenfide, Iprobenfos, Iprovalicarb, Isoprocarb, Isoprothiolane, Isopyrazam, Kresoxim-methyl, Linuron, Lufenuron, Lufenuron, Malathion, Mandipropamid, Mefenacet, Mepanipyrim, Mepanipyrim, Mepronil, Metalaxyl, Metamifop, Metazosulfuron, Metconazole, Methabenzthiazuron, Methiocarb, Methomyl, Methoxyfenozide, Metobromuron, Metolcarb, Metrafenone, Mevinphos, Milbemectin A3, Milbemectin A4, Molinate, Monocrotophos, Myclobutanil, Napropamide, Nicosulfuron, Novaluron, Nuarimol, Ofurace,Omethoate, Oxadiazon, Oxadixyl, Oxamyl, Oxaziclomefone, Paclobutrazole, Penconazole, Pencycuron, Penoxsulam, Pentoxazone, Phenthoate, Phosphamidone, Phoxim, Piperophos, Pirimicarb, Pirimiphos-methyl, Probenazole, Profenofos, Propamocarb, Propanil, Propaquizafop, Propoxur, Pyraclofos, Pyraclostrobin, Pyrazolate, Pyrazophos, Pyribenzoxim, Pyributicarb, Pyrida ben, Pyridaphenthion, Pyrifluquinazon, Pyriftalid, Pyrimethanil, Pyrimidifen, Pyriminobac-methyl(E), Pyriminobac-methyl(Z), Pyrimisulfan, Pyriproxyfen, Pyroquilon, Quinalphos, Quinmerac, Quinoclamine, Quizalofop-ethyl, Saflufenacil, Sethoxydim, Spinetoram(j), Spinetoram(L), Spirodiclofen, Spirotetramat, Sulfoxaflor, Tebuconazole, Tebufenozide, Tebufenpyrad, Teflubenzuron, Terbuthylazine, Tetraconaole, Thenylchlor, Thiabendazole, Thiacloprid, Thiamethoxam, Thiazopyr, Thidiazuron, Thifensulfuron-methyl, Thiobencarb, Thiodicarb, Tiadinil, Triadimefon, Triazophos, Tricyclazole, Trifloxystrobin, Triflumizole, Triflumuron, Uniconazole, Vamidothion 
Supplementary material 2. Flow rates and timing for liquid chromatography mass spectrometry conditions

\begin{tabular}{|c|c|c|c|}
\hline \multirow{2}{*}{ Time (min) } & \multicolumn{2}{|c|}{ Mobile phase } & \multirow{2}{*}{ Flow (mL/min) } \\
\hline & $A(\%)$ & $\mathrm{B}(\%)$ & \\
\hline Initial & 85 & 15 & 0.3 \\
\hline 1 & 85 & 15 & 0.3 \\
\hline 1.5 & 40 & 60 & 0.3 \\
\hline 10 & 10 & 90 & 0.3 \\
\hline 12 & 10 & 90 & 0.3 \\
\hline 12.1 & 2 & 98 & 0.3 \\
\hline 16 & 2 & 98 & 0.3 \\
\hline 20 & 85 & 15 & 0.3 \\
\hline
\end{tabular}

